\title{
Improvement of zein dough characteristics using dilute organic acids
}

\author{
Alexandra C. Sly, Janet Taylor and John R.N. Taylor*
}

Institute for Food, Nutrition and Well-being and Department of Food Science, University of Pretoria, Private Bag X 20, Hatfield 0028, South Africa

${ }^{*}$ Corresponding Author: John R.N. Taylor

Phone: +27 124204296

Fax: +27 124202839

E-mail: john.taylor@up.ac.za

Running title: Zein dough improvement

Keywords: zein, organic acids, gluten-free, organic acids, rheology, fibrils

Abbreviations: $\mathrm{T}_{\mathrm{g}}$, glass transition temperature; SDS-PAGE, sodium dodecyl sulphatepolyacrylamide gel electrophoresis; FTIR, fourier transform infrared spectroscopy; CLSM, confocal laser scanning microscopy. 


\section{HIGHLIGHTS}

Lactic and acetic acids increase zein dough extensibility but maintain cohesiveness

Fine and uniform zein dough fibril structure is formed with acid preparation

Zein-starch doughs prepared with acids can hold air and be inflated by Alveography

Zein dough improvement apparently due to change in secondary structure

\section{Abstract}

The replacement of gluten in dough products poses a major challenge. Preparing zein doughs in dilute acetic acid and lactic acid, such as produced during sourdough fermentation, was investigated. Increasing acid concentrations $(0.7,1.3$ and $5.4 \%[\mathrm{v} / \mathrm{v}])$ increased zein extensibility and reduced the stress and related parameters. Preparation of zein-maize starch/rice doughs in dilute organic acids improved dough properties to the extent that the doughs could hold air and be inflated into a bubble by Alveography. Further, they exhibited similar Stability (P), Distensibility and deformation energy (W) to wheat flour dough. Confocal laser scanning microscopy revealed an ordered linear fibril network in zein and zein-rice flour doughs prepared in the dilute acids, which became uniform with increasing acid concentration. SDS-PAGE showed that the acids did not hydrolyse or polymerise the zein. FTIR indicated that the acidic conditions slightly increased the proportion of $\alpha$-helical conformation in the zein doughs, possibly as a result of deamination. This conformational change may be responsible for the considerably improved zein dough properties. Zein doughs prepared in dilute organic acids show potential as a gluten replacement in gluten-free formulations. 


\section{Introduction}

Replacement of wheat gluten functionality in gluten-free dough-based formulations such as bread poses a major challenge to food scientists (Gallagher et al., 2004). Viscoelasticity is the critical attribute of gluten that allows the retention of carbon dioxide produced during dough fermentation (Erickson et al., 2011). Zein (maize prolamin prolamin) can display viscoelastic functionality similar to gluten in aqueous dough systems, when heated above its glass transition temperature $\left(\mathrm{T}_{\mathrm{g}}\right.$ ) (Lawton 1992; Schober et al., 2008; Schober et al., 2010). These zein doughs exhibit a fibrous network (Lawton 1992; Schober et al., 2008; Andersson et al., 2011), which also displays similar characteristics to that in gluten dough. However, such zein-based doughs have a limited ability to retain gas (Schober et al., 2008) and are significantly more extensible than gluten-based doughs (Schober et al., 2010). Hydrocolloids such as hydroxypropyl methylcellulose (HPMC) have been found to stabilize the fibrous zein structure in the dough, enabling the bread of fair quality to be produced (Schober et al. 2008; Schober, et al. 2010; Andersson et al. 2011).

The incorporation of sourdough (mixed lactic acid bacteria and yeast fermented dough) into a wheat bread system causes a significant increase in loaf volume (Katina et al., 2005). Edema et al. (2013) showed that the inclusion of fonio and sorghum sourdough improved fonio and sorghum dough properties and increased the loaf volume of the resulting breads to a limited extent. Their findings indicated that the sourdough fermentation modified the starch pasting properties. Schober et al. (2007) showed that sourdough fermentation resulted in hydrolysis of proteins in sorghum doughs and caused the endosperm protein matrix in the crumb of sorghum breads to be disaggregated. They proposed that this protein matrix disaggregation enabled the formation of stronger starch gels in such gluten-free breads.

An important related question is whether the dilute organic acids produced in sourdough-type fermentations also affect the functional properties of the non-wheat prolamins. Here, we report on their effects on the functionality of aqueous zein doughs.

\section{Experimental}




\subsection{Materials}

Commercial zein (Sigma Z3625) was obtained from Sigma-Aldrich, Johannesburg, South Africa. Maize starch (Maizena, Bokomo Foods, Atlantis, South Africa) and bread wheat flour (SnowFlake, Premier Foods, Isando, South Africa) were obtained from retail stores. Rice flour (Entice $100 \%$ Pure Rice Flour) was kindly donated by Daisy Health Foods, Johannesburg.

\subsection{Preparation of zein doughs}

Zein doughs were prepared essentially according to Schober et al. (2010) except that the zein was used without defatting. Zein $\left(0.5 \mathrm{~g}\right.$ as is basis) was pre-warmed to $40^{\circ} \mathrm{C}$. Distilled water, $0.7 \%, 1.3 \%$ and $5.4 \%(\mathrm{v} / \mathrm{v})$ lactic and acetic acid (1.875 g) were pre-warmed separately. The liquid was added to the zein and vortexed at high speed for $5 \mathrm{~s}$. Excess water or acid was decanted off the dough and the dough was hand-kneaded for $30 \mathrm{~s}$. Zein-maize starch and zein-rice flour doughs ( $1 \mathrm{~g}$ zein: $4 \mathrm{~g}$ starch or rice flour, as is basis) were prepared in the same way.

\subsection{Zein tensile properties}

The tensile properties of the zein doughs were evaluated using a Kieffer rig (Abang Zaidel et al., 2008), mounted on a TA-XT2 texture analyzer (Stable Micro Systems, Godalming, UK). The doughs were pressed into a cylindrical, longitudinally split rubber tube mould $(70 \mathrm{~mm}$ long and $4 \mathrm{~mm}$ diameter) to obtain a uniform size and shape. The moulded samples were placed over the vertical struts (30 mm apart) of the Kieffer rig and clamped in place at both ends. Doughs were extended by means of a hook centred over the sample at a constant rate of $3.3 \mathrm{~mm} / \mathrm{s}$ over a distance of $150 \mathrm{~mm}$ (maximum displacement of the texture analyser). The test was performed at ambient temperature $\left(22^{\circ} \mathrm{C}\right)$ and within $2 \mathrm{~min}$, to prevent the doughs from cooling below their glass transition temperature. The force over distance, peak force $(\mathrm{N})$, extensibility until rupture $(\mathrm{mm})$ and area under the curve $(\mathrm{N} \times \mathrm{mm})$ were measured. Rheological parameters were determined using formulae according to Abang Zaidel et al. (2008).

\subsection{Alveography}

Alveography (Chopin NG Consistograph, Paris) was used to analyse the quality of glutenfree doughs made from zein-maize starch and zein-rice flour mixtures (1:4) prepared with 
different concentrations of lactic acid and acetic acid, according to ICC Standard 121 (ICC, 1992). Zein (50 $\mathrm{g}$ as is basis) was added to $200 \mathrm{~g}$ (as is basis) maize starch or rice flour and thoroughly mixed using an electric mixer for $5 \mathrm{~min}$. The "flour" was then pre-warmed to $50^{\circ} \mathrm{C}$ in water bath. The flour was then transferred to the mixing section of the Alveograph. Pre-warmed distilled water (200 g) was slowly added and the dough kneaded for $8 \mathrm{~min}$, formed into round patties and allowed to rest for $20 \mathrm{~min}$ before inflation took place. Dough kneading and resting was conducted at a temperature of $35^{\circ} \mathrm{C}$ (the highest instrument setting). Alveography was performed and $\mathrm{P}, \mathrm{L}, \mathrm{P} / \mathrm{L}$ and $\mathrm{W}$ recorded.

\subsection{CLSM}

Zein mixed in water at $22^{\circ} \mathrm{C}$, zein doughs and zein-starch/rice flour gluten-free doughs prepared at $40^{\circ} \mathrm{C}$ were analysed by Confocal Laser Scanning Microscopy (CLSM) using a Zeiss 510 META system (Jena, Germany) with a Plan-Neofluar 10 x 0.3 objective under natural fluorescence at an excitation wavelength of $488 \mathrm{~nm}$. The doughs were prepared as described under 2.2. Thin pieces of freshly prepared dough (approx. 5 x $5 \mathrm{~mm}$ diameter and 2 $\mathrm{mm}$ thick) as is, and zein dough and zein-rice flour dough stretched in a single direction to over a glass slide to approx. 15 x $5 \mathrm{~mm}$ x $1 \mathrm{~mm}$, were examined.

\subsection{SDS-PAGE}

The zein doughs air-dried at ambient temperature were characterized by SDS-PAGE under reducing and non-reducing conditions using 4-12\% polyacrylamide gradient gels $(8 \times 8 \mathrm{~cm}$ x1.0 mm thick with 15 wells) (NuPAGE® Novex, Invitrogen. Carlsbad, CA). Invitrogen Mark12 Unstained Standard was used. Zein sample loading was $10 \mu \mathrm{g}$. Staining was with Coomassie Brilliant Blue R-250. After de-staining, the gels were scanned on a flatbed scanner.

\subsection{FTIR}

FTIR spectroscopy was performed on zein and freshly prepared zeins doughs, as described by Taylor et al. (2009). A Vertex 70v FTIR spectrophotometer (Bruker Optik, Ettlingen, Germany) was used in the attenuated total reflectance (ATR) mode with 64 scans, an $8 \mathrm{~cm}^{-1}$ band width, and an interval of $1 \mathrm{~cm}^{-1}$ at a wave number $400-4000 \mathrm{~cm}^{-1}$. To minimise cooling effects, there was a maximum $30 \mathrm{~s}$ delay from the moment the samples were removed following dough formation at $40^{\circ} \mathrm{C}$ to the start of the FTIR scan. At least four replicates were 
performed for each treatment. The FTIR spectra were Fourier deconvoluted with a Lorentzian filter with a band width of 12 and a resolution enhancement factor of 2 .

\subsection{Statistical analysis}

The zein tensile, zein-starch/-rice flour Alveography and FTIR experiments were repeated at least three times. One-way analysis of variance was performed. Means were compared at $\mathrm{p}=$ 0.05 using Fischer's Least Significant Difference Test (LSD).

\section{Results and Discussion}

\subsection{Zein doughs}

The pHs of all the zein doughs were below pH 4 (Table 1). With increasing lactic acid and acetic concentration dough $\mathrm{pH}$ was progressively reduced. Doughs prepared in the acids all had pHs below pH 3.5, somewhat below a typical sourdough pH of 3.6-4.0 (Edema et al., 2013).

The zein doughs were all highly extensible and reached the maximum possible extension on the Kieffer rig $(270 \mathrm{~mm})$ without breaking (Table 1). Unfortunately, it was not practical to make a zein dough piece that was smaller and still perform the tensile tests. However, when the doughs were extended by hand it was found that there was a progressive increase in extensibility with both lactic acid and acetic acid concentration, from $175 \mathrm{~mm}$ with dough prepared with water to, for example, $341 \mathrm{~mm}$ with dough prepared in $5.4 \%$ acetic acid. The fact that the zein doughs were very extensible confirmed findings by Lawton (1992) who was able to extend zein starch doughs, mixed at $30^{\circ} \mathrm{C}$ and $35^{\circ} \mathrm{C}$, the entire length of an Extensigraph without them breaking.

Increasing lactic acid and acetic acid concentration also resulted in a progressive and substantial reduction in the strength of the zein dough. The peak stress of the zein dough prepared in $5.4 \%$ lactic acid $(18.2 \mathrm{kPa})$ was only $15 \%$ of that of dough prepared in water and that of the dough prepared in $5.4 \%$ acetic acid $(9.0 \mathrm{kPa})$ only $8 \%$. This reduction dough strength and high extensibility was accompanied by concomitant reductions in extensional viscosity, modulus of elasticity (Young's Modulus) and area under the stress-strain curve. This shows that the acids reduced the strength of the zein dough but its cohesion was maintained. These effects of dilute organic acids on zein dough tensile properties are similar 
to those resulting from defatting zein (Schober et al., 2010). These authors found that defatting commercial zein with chloroform resulted in the zein doughs being more cohesive, extensible and smoother. They attributed this to better aggregation of the zein particles into dough strands as a result of removal of lipids from the surface of the zein particles.

CLSM showed that zein mixed in water at $22^{\circ} \mathrm{C}$ simply comprised a mass of protein particles (Fig. 1A a). However, when the zein transformed into a dough by mixing at $40^{\circ} \mathrm{C}$, i.e. above its $T_{g}$, the dough appeared as fibrils, aligned together in larger fibres and the fibres were randomly orientated (Fig 1A b). From CLSM, Schober et al. (2010) suggested that the aggregation of zein particles into strands (fibrils/fibres) is a critical step in dough formation. Forming the doughs in dilute lactic acid or acetic acid seemed to cause aggregation of fibres and their orientation in the same direction (Fig. 1A c-f), in agreement with the strong dough cohesiveness, demonstrated by the dough tensile properties (Table 1). According to Erickson et al. (2011) zein's reactivity is increased above its $T_{g}$ and thus its propensity for aggregation and crosslinking is enhanced, which allows for the development of extensive fibrous protein networks similar to those seen in wheat doughs. Dilute lactic acid and acetic acid clearly promoted this process of aggregation.

Stretching the zein doughs in a single direction resulted in alignment of all the fibrils in the direction of stretching, with the fibrils being approx. $3 \mu \mathrm{m}$ diameter (Fig. 1B b-f). With the dough formed in water there were large inclusions in the dough, presumably particles of zein that had not fully transformed into dough (Fig. 1B a). However, formation of the doughs in dilute lactic acid and acetic acid resulted in much improved transformation of zein into dough (Fig. B c-f) with essentially no inclusions at the higher acid concentration (5.4\%). Further, the fibril mass was very uniform. The reduced strength, increased extensibility but maintained cohesiveness of the doughs with increasing acid concentration (Table 1) is presumably related to the very uniform structure of the dough and linear orientation of the fibrils.

SDS-PAGE was performed to establish whether the zein dough tensile property changes and fibril formation brought about mixing under acid conditions were as result of either hydrolysis or covalent polymerisation of the zein. Under non-reducing conditions all the doughs showed the presence of zein monomers, dimers and trimers. There was no difference in their proportions between the samples (Fig. 2). Under reducing conditions, in all doughs 
there was an increase in the relative proportion of zein monomers and a decrease in the proportion of trimers, as a result of disulphide bond breakage (Emmambux and Taylor, 2009). However, there was no difference in the relative proportions of monomers, dimers and trimers between different doughs. Thus, the effect of the acidic conditions on zein dough properties were not due to zein covalent bond hydrolysis or polymerisation. Similarly, Zhang et al. (2011), working with zein dissolved in aqueous ethanol adjusted to a range of pHs with $\mathrm{HCl}$ or $\mathrm{NaOH}$ did not find any evidence of "fragmentation" or oligomerisation. This is unlike the situation in gluten dough formation where disulphide bond-sulphydryl group interchange is believed to play a crucial role in dough development (Wieser, 2012).

Possible effects of the acidic conditions on zein secondary structure were investigated by FTIR (Table 2). The supplementary materials show the FTIR spectra. The dry zein powder had predominantly $\alpha$-helical conformation (60\%), as indicated it is Amide I spectrum (Duodu et al., 2001; Kong and Yu, 2007). With preparation of zein in distilled water and in dilute lactic and acetic acids, the relative proportion of the $\alpha$-helical to $\beta$-sheet conformation was substantially diminished. However, as the concentration of organic acid increased, there was an increase in the proportion of $\alpha$-helical conformation. This was particularly evident at the highest concentration of organic acids (5.4\%) where the relative proportion was $55-56 \%$.

According to Shewry and Tatham (1990) there is between 40 and 60\% $\alpha$-helical conformation present in the secondary structure of $\alpha$-zein, and only a small amount of $\beta$-sheet conformation is present, when the protein is dissolved in aqueous ethanol. Recent literature attributes the high extensibility demonstrated by zein doughs above their $\mathrm{T}_{\mathrm{g}}$ being most probably due to the high amount of $\beta$-sheet conformation present in the protein under these conditions (Erickson et al., 2011). Mejia et al. (2007) found that the amount of $\beta$-sheet conformation present in zein increased from 30 to $48 \%$ when the protein was raised above its $\mathrm{T}_{\mathrm{g}}$. This present work is consistent with this finding. Mejia et al. (2007) further found that the $\beta$-sheet content decreased significantly, back to $30 \%$, when the temperature of the zein polymer was reduced from 35 to $25^{\circ} \mathrm{C}$, coinciding with a loss of viscoelasticity of the zein polymer.

The cohesive property (Table 1) and uniform texture (Fig. 1A d,f) of these zein doughs prepared in dilute lactic and acetic acids may have been the result of the increase in $\alpha$-helical conformation of the zein. Zhang et al. (2011) found that the rheological properties of zein 
dissolved in aqueous ethanol were altered when the $\mathrm{pH}$ was adjusted to both acidic and basic pHs. It exhibited decreased viscosity, elastic modulus and viscous modulus. They further found that both high and low $\mathrm{pH}$ decreased the contents of $\alpha$-helix, $\beta$-sheet and $\beta$-turn (but not random coil) of the zein in aqueous ethanol solution. They attributed these secondary structural changes to deamination of the zein. Deamidation may also have been responsible for the observed secondary structure conformational changes in the zein when in the form a dough

\section{Zein-maize starch/rice flour doughs}

When zein-maize starch and zein-rice flour were mixed with the Alveograph dough mixer using distilled water only, a soft, lumpy mixture was formed, which did not exhibit extensible dough-like properties and was easily pulled apart. If left for a short resting period, severe phase separation took place, with water containing starch leaching out of the mass (Fig. 3A). Thus, it was not possible to test the properties of these "doughs" using the Alveograph. Mixing the zein-starch/-rice flour with dilute lactic acid or acetic acid dramatically improved the quality of the doughs (Fig. 3B,C). The doughs could hold air and inflate a dough bubble when subjected to Alveography (Fig. 2D). However, irrespective of dough type or acid concentration, in all cases the dough bubble developed small tears or holes (Fig. 3E), which prevented the growth of bubbles to a similar in size to those obtained with wheat flour dough.

Table 3 shows that Alveograph dough quality parameters of the zein-maize starch and zeinrice flour doughs were similar and that they were both similarly affected by lactic acid and acetic concentration. Both dough Stability (P) and Distensibility (L) were much higher with the low concentrations of acid (0.7 and $1.3 \%)$ than with the high acid concentration $(5.4 \%)$. Zein-starch/-rice flour doughs formed using the lower concentrations of lactic and acetic acid (0.7 and $1.3 \%$ ) had similar Stability to the wheat flour dough and $\mathrm{P}$ was much lower for doughs prepared in $5.4 \%$ acid. In contrast, with the exception of the zein-maize starch dough prepared in $0.7 \%$ lactic acid, these lower acid concentrations resulted in doughs with lower Distensibility than the wheat flour dough and $5.4 \%$ acid produced doughs with similar L values to the wheat flour dough. Overall, the zein-maize starch dough prepared in $0.7 \%$ lactic had the most similar P and L values to the wheat flour dough, 75.4 and 81.6 versus 103.2 and 79.6, respectively. With regard to the important $\mathrm{P} / \mathrm{L}$ ratio parameter, which provides information on the elastic resistance and extensibility balance of a flour (Rosell et al., 2001), with the exception of the zein rice-flour dough prepared in $5.4 \%$ lactic acid, the P/L ratio of 
the zein-based dough was considerably less than 1. This is indicative of high dough extensibility and low elastic resistance and reflects the effects of the acids on zein tensile properties (Table 1). It is also probably why the doughs developed tears and holes. With regard to dough deformation energy (W), 1.3\% lactic or acetic acid resulted in doughs with a very similar W to the wheat flour dough. Visual observation of dough bubble inflation indicated the zein-rice flour doughs prepared in 0.7 and $1.3 \%$ lactic acid had the best Alveography properties. The very positive effect of lactic acid and acetic acid on the functional properties of zein-starch/rice doughs has similarities to that found by Lawton (1992) with zein-starch doughs containing the plasticizer dibutyl tartrate (Fordyce and Meyer, 1940). The zein-starch doughs containing dibutyl tartrate had much greater Extensigraph extensibility than simple zein-doughs (Lawton, 1992). The author suggested that the dibutyl tartrate was either behaving as classical plasticizer or acting a type of lubricant.

CLSM of the stretched zein-rice flour doughs showed that doughs formed in distilled water at $40^{\circ} \mathrm{C}$ did not exhibit fibrils (Fig. 1C b), unlike the zein only doughs (Fig. 1A b), but there was a matrix of protein around the starch granules (Fig. 1Cb). The matrix was not formed at the $22^{\circ} \mathrm{C}$ mixing temperature (Fig. $1 \mathrm{C} \mathrm{a}$ ), below the zein $\mathrm{T}_{\mathrm{g}}$. In contrast to dough formed in distilled water at $40^{\circ} \mathrm{C}$, doughs formed in dilute acids at this temperature all contained linearly orientated fibrils (Fig. 1C c-e), similar to those in the zein only doughs (Fig. 1B c-f). The fibrils were continuous throughout the dough mass and enveloped the rice flour starch granules. With the $1.3 \%$ acetic acid treatment, the protein matrix around the starch granules was still evident (Fig. 1C e). However, with the acetic acid 5.4\% treatment (Fig. 1C f) and with both lactic acid treatments (Fig. $1 \mathrm{C}$ cd) the matrix was no longer present. This indicates improved zein dough formation with these treatments.

These effects of dilute lactic acid and acetic acid on the structure of zein-rice flour dough seem to be similar to the effect of hydrocolloid addition to zein-starch doughs. This also resulted in a finer protein network (Schober et al., 2008; Andersson et al., 2011). Schober et al. (2008) hypothesized that the addition of hydrocolloids, resulted in weaker interactions between zein protein chains, which may have contributed to the tendency of zein to form very extendable strands. In this present work, it appears that the extendable and cohesive properties of the zein doughs induced by dilute organic acids, which enabled the zeinstarch/rice flour doughs to hold air and inflate into a bubble when subjected to Alveography, 
were related to a conformational change in zein (Table 2).

\section{Conclusions}

Preparation of zein dough with dilute organic acids, lactic acid and acetic acid, above its $\mathrm{T}_{\mathrm{g}}$ greatly improves dough functionality. The acidic conditions somewhat reverses the change from predominantly $\alpha$-helical to more $\beta$-sheet conformation, which occurs when zein is made into a dough. The increase in $\alpha$-helical conformation possibly occurs as a result of deamination of the zein molecules. This in turn enables the formation of a more uniform dough structure with linear orientation of fibrils. This change in structure considerably improved zein dough properties in terms of extensibility while retaining cohesiveness, which enables zein-starch/-rice flour doughs to hold air and be inflated into a bubble by Alveography. Thus, zein dough preparation with dilute organic acids has potential as a practical alternative to gluten in gluten-free formulations.

\section{References}

Abang Zaidel, D.N., Chin, N.L., Abdul Rahman, R., Karim, R. 2008. Rheological characterization of gluten from extensibility measurement. Journal of Food Engineering 86, 549-556.

Andersson, H., Öhgren, C., Johansson, D., Kniola, M., Stading, M. 2011. Extensional flow, viscoelasticity and baking performance of gluten-free zein-starch doughs supplemented with hydrocolloids. Food Hydrocolloids 25, 1587-1595

Duodu, K.G., Tang, H., Grant, A., Wellner, N., Belton, P.S., Taylor, J.R.N. 2001. FTIR and solid state 13C NMR spectroscopy of proteins of wet cooked and popped sorghum and maize. Journal of Cereal Science 33, 261-269.

Edema, M.O., Emmambux, M.N., Taylor J.R.N. 2013. Improvement of fonio dough properties through starch modification by sourdough fermentation. Starch/Stärke 65, 730737. 
Emmambux, M.N., Taylor, J.R.N. 2009. Properties of heat-treated sorghum and maize meal and their prolamin proteins. Journal of Agricultural and Food Chemistry 57, 1045-1050.

Erickson, D.P., Campanella, O.H., Hamaker, B.R. 2011. Functionalizing maize zein in viscoelastic dough systems through fibrous, $\beta$-sheet-rich protein networks: An alternative, physiochemical approach to gluten-free breadmaking Trends in Food Science and Technology 24, 74-81.

Fordyce, C.R., Meyer, L.W.A. 1940. Plasticizers for cellulose acetate and cellulose acetate butyrate. Industrial and Engineering Chemistry 32, 1053-1060.

Gallagher, E., Gormley, T.R., Arendt, E.K. 2004. Recent advances in the formulation of gluten-free cereal-based products. Trends in Food Science and Technology 15, 143-152.

ICC. 1992. Standard Method No. 121. Method for using of the Chopin Alveograph (Rheological Properties). International Association for Cereal Science and Technology, Vienna.

Katina, K., Heiniö, L.R., Autio, K., Poutanen, K. 2005. Optimization of sourdough process for improved sensory profile and texture of wheat bread. LWT - Food Science and Technology 39, 1189-1202.

Kong, J., Yu, S. 2007. Fourier transform infrared spectroscopic analysis of protein secondary structures. Acta Biochimica et Biophysica Sinica 39, 549-559.

Lawton, J.W. 1992. Viscoelasticity of zein-starch doughs. Cereal Chemistry 69, 351-355.

Mejia, C.D., Mauer, L.J., Hamaker, B.R. 2007. Similarities and differences in secondary structure of visco-elastic polymers of maize $\alpha$-zein and wheat gluten proteins. Journal of Cereal Science 45, 353-359.

Rosell, C.M., Rojas, J.A., Benedito de Barber, C. 2001. Influence of hydrocolloids on dough rheology and bread quality. Food Hydrocolloids 15, 75-81. 
Schober, T.J, Bean, S.R., Boyle, D.L. 2007. Gluten-free sorghum bread improved by sourdough fermentation: biochemical, rheological, and microstructural background. Journal of Agricultural and Food Chemistry 55, 5137-5146

Schober, T.J., Bean, S.R., Boyle, D.L., Park, S. 2008. Improved viscoelastic zein-starch doughs for leavened gluten-free breads: Their rheology and microstructure. Journal of Cereal Science 48, 755-767.

Schober, T.J., Moreau, R.A, Bean, S.R., Boyle, D.L. 2010. Removal of surface lipids improves the functionality of commercial zein in viscoelastic zein-starch dough for glutenfree bread making. Journal of Cereal Science 52, 417-425.

Shewry, P.R., Tatham, A.S. 1990. The prolamin storage proteins of cereal seeds: structure and evolution. Biochemistry Journal 267, 1-12.

Taylor, J., Taylor, J.R.N., Belton, P.S. and Minnaar, A. 2009. Preparation of free-standing films from kafirin protein microparticles: mechanism of formation and functional properties. Journal of Agricultural and Food Chemistry 57, 6729-6735.

Wieser, H., 2012. The use of redox agents in breadmaking. In: Cauvain, S.P. (Ed.), Bread Making: Improving Quality, 2 nd ed. Woodhead Publishing, Cambridge, pp. 447-469.

Zhang, B., Luo, Y., Wang, Q. 2011. Effect of acid and base treatments on structural, rheological and antioxidant properties of $\alpha$-zein. Food Chemistry 124, 210-220. 


\section{LEGENDS TO FIGURES}

Fig, 1 CLSM of zein and zein-rice flour doughs prepared with distilled water and dilute lactic and acetic acid

\section{A. Zein doughs without stretching}

a, Distilled water at $22^{\circ} \mathrm{C}$; b, Distilled water at $40^{\circ} \mathrm{C}$; c, $1.3 \%$ lactic acid at $40^{\circ} \mathrm{C} ; \mathrm{d}, 5.4 \%$ lactic acid at $40^{\circ} \mathrm{C}$; e, $1.3 \%$ acetic acid at $40^{\circ} \mathrm{C}$; f, $5.4 \%$ acetic acid at $40^{\circ} \mathrm{C}$.

\section{B. Zein doughs stretched by hand}

a, Distilled water at $22^{\circ} \mathrm{C}$ (since it did not form a dough it could not be stretched); b, distilled water at $40^{\circ} \mathrm{C} ; \mathrm{c}, 1.3 \%$ lactic acid at $40^{\circ} \mathrm{C} ; \mathrm{d}, 5.4 \%$ Lactic acid at $40^{\circ} \mathrm{C}$; e, $1.3 \%$ acetic acid at $40^{\circ} \mathrm{C}$; f, $5.4 \%$ acetic acid at $40^{\circ} \mathrm{C}$. Arrows indicate zein particles and other discontinuities in the dough mass.

\section{Zein-rice flour doughs stretched by hand}

a, distilled water at $22^{\circ} \mathrm{C}$; b, distilled water at $40^{\circ} \mathrm{C}$; c, $1.3 \%$ lactic acid at $40^{\circ} \mathrm{C} ; \mathrm{d}, 5.4 \%$ acetic acid at $40^{\circ} \mathrm{C} ; 1.3 \%$ acetic acid at $40^{\circ} \mathrm{C} ; \mathrm{f}, 5.4 \%$ acetic acid at $40^{\circ} \mathrm{C}$. Arrows indicate flour particles. Dotted arrows indicate starch granules.

Fig. 2 SDS-PAGE of zein doughs prepared with dilute lactic acid and acetic acid A, Molecular standards; B, Zein in distilled water; C, Zein in $0.7 \%$ lactic acid; D, Zein in $1.3 \%$ lactic acid; E, Zein in 5.4\% lactic acid; F, Zein in $0.7 \%$ acetic acid; G, Zein in $1.3 \%$ acetic acid; $\mathrm{H}$, Zein in $5.4 \%$ acetic acid.

Fig. 3 Zein-maize starch doughs

A, Dough prepared with water after kneading, showing phase separation; B, Dough prepared with $1.3 \%$ lactic acid after kneading; C, Malleability of dough prepared with $1.3 \%$ lactic acid; D, Alveography of dough prepared with $1.3 \%$ lactic acid; E, Loss of uniformity and tearing of Alveograph bubble of dough prepared with 5.4\% lactic acid. 

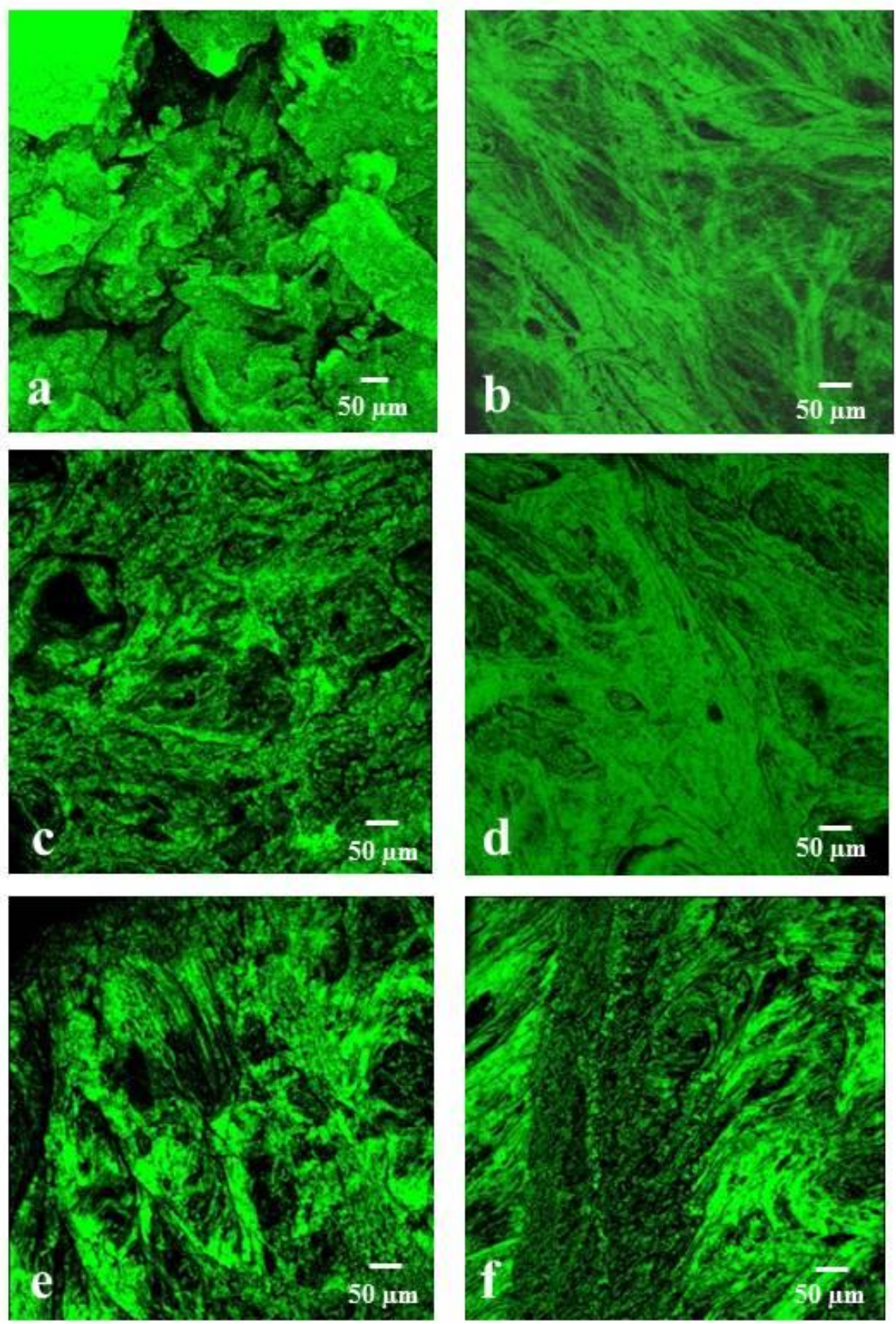

Fig. 1A. Zein doughs without stretching

a, Distilled water at $22^{\circ} \mathrm{C}$; b, Distilled water at $40^{\circ} \mathrm{C}$; c, $1.3 \%$ lactic acid at $40^{\circ} \mathrm{C}$; d, $5.4 \%$ lactic acid at $40^{\circ} \mathrm{C} ; \mathrm{e}, 1.3 \%$ acetic acid at $40^{\circ} \mathrm{C} ; \mathrm{f}, 5.4 \%$ acetic acid at $40^{\circ} \mathrm{C}$. 

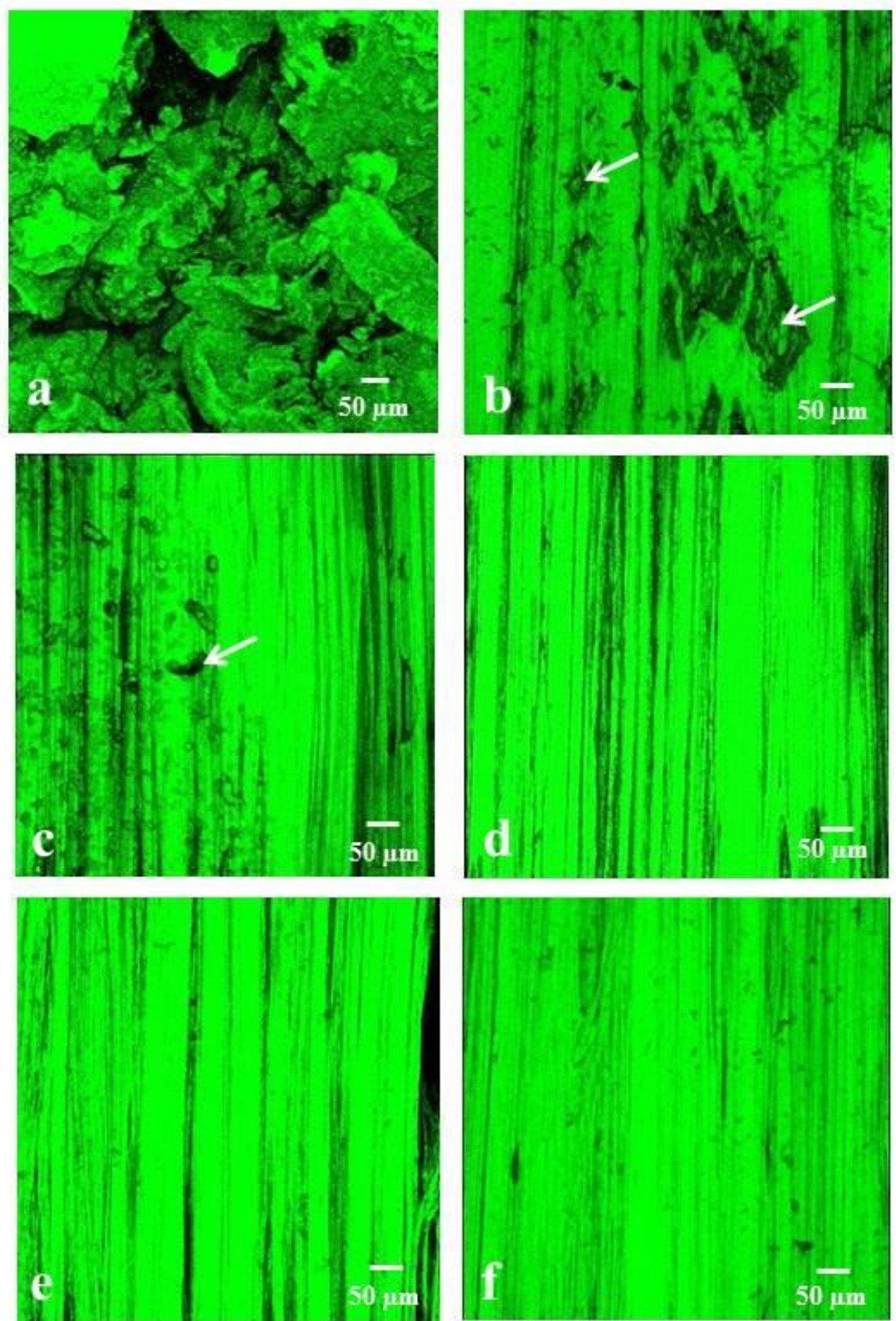

\section{Fig. 1B. Zein doughs stretched by hand}

a, Distilled water at $22^{\circ} \mathrm{C}$ (since it did not form a dough it could not be stretched);

b, distilled water at $40^{\circ} \mathrm{C} ; \mathrm{c}, 1.3 \%$ lactic acid at $40^{\circ} \mathrm{C} ; \mathrm{d}, 5.4 \%$ Lactic acid at $40^{\circ} \mathrm{C} ; \mathrm{e}, 1.3 \%$ acetic acid at $40^{\circ} \mathrm{C}$;

f, $5.4 \%$ acetic acid at $40^{\circ} \mathrm{C}$. Arrows indicate zein particles and other discontinuities in the dough mass. 

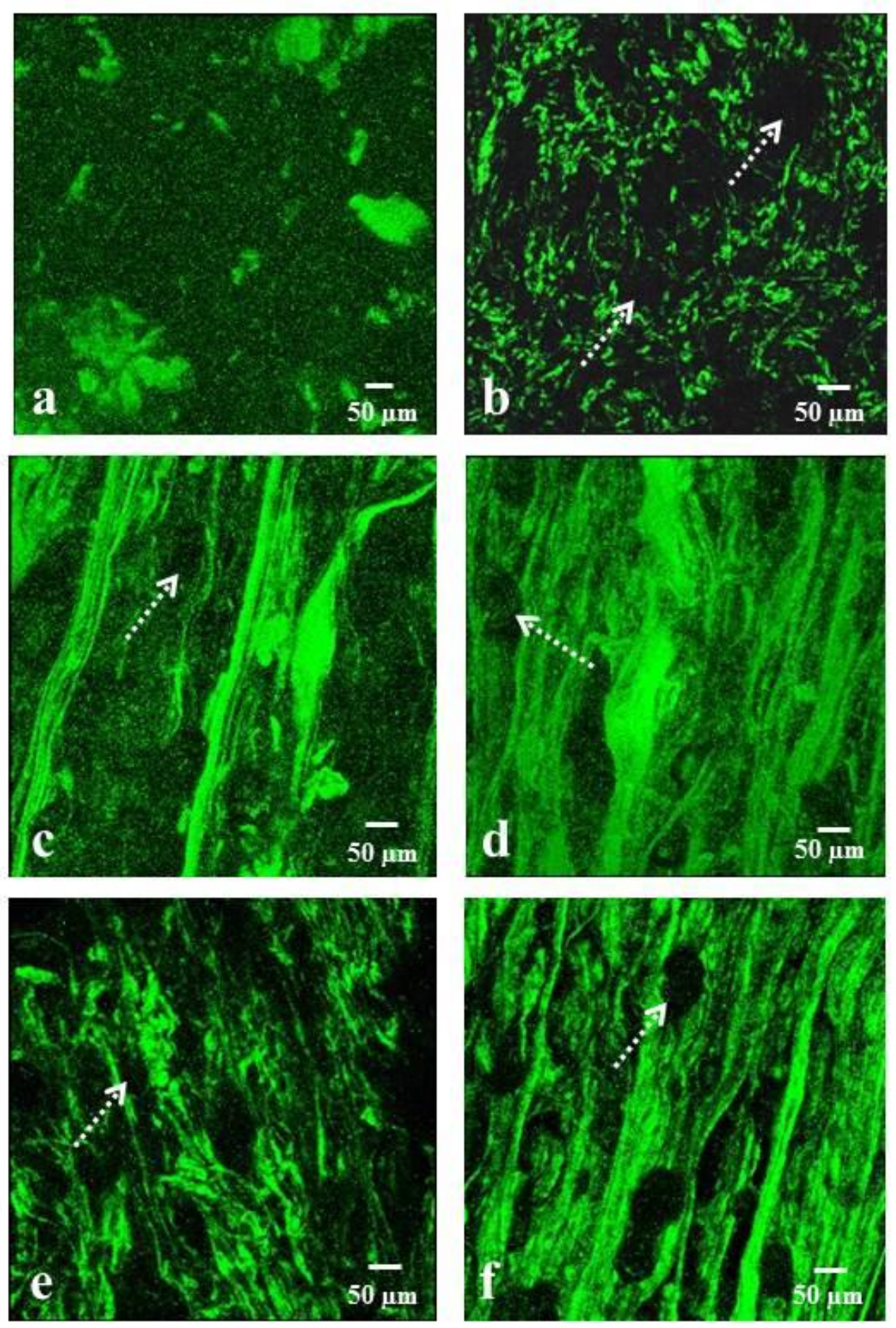

Fig 1C. Zein-rice flour doughs stretched by hand

a, distilled water at $22^{\circ} \mathrm{C} ; \mathrm{b}$, distilled water at $40^{\circ} \mathrm{C} ; \mathrm{c}, 1.3 \%$ lactic acid at $40^{\circ} \mathrm{C}$; d, $5.4 \%$ acetic acid at $40^{\circ} \mathrm{C} ; 1.3 \%$ acetic acid at $40^{\circ} \mathrm{C} ; \mathrm{f}, 5.4 \%$ acetic acid at $40^{\circ} \mathrm{C}$. Arrows indicate flour particles. Dotted arrows indicate starch granules. 


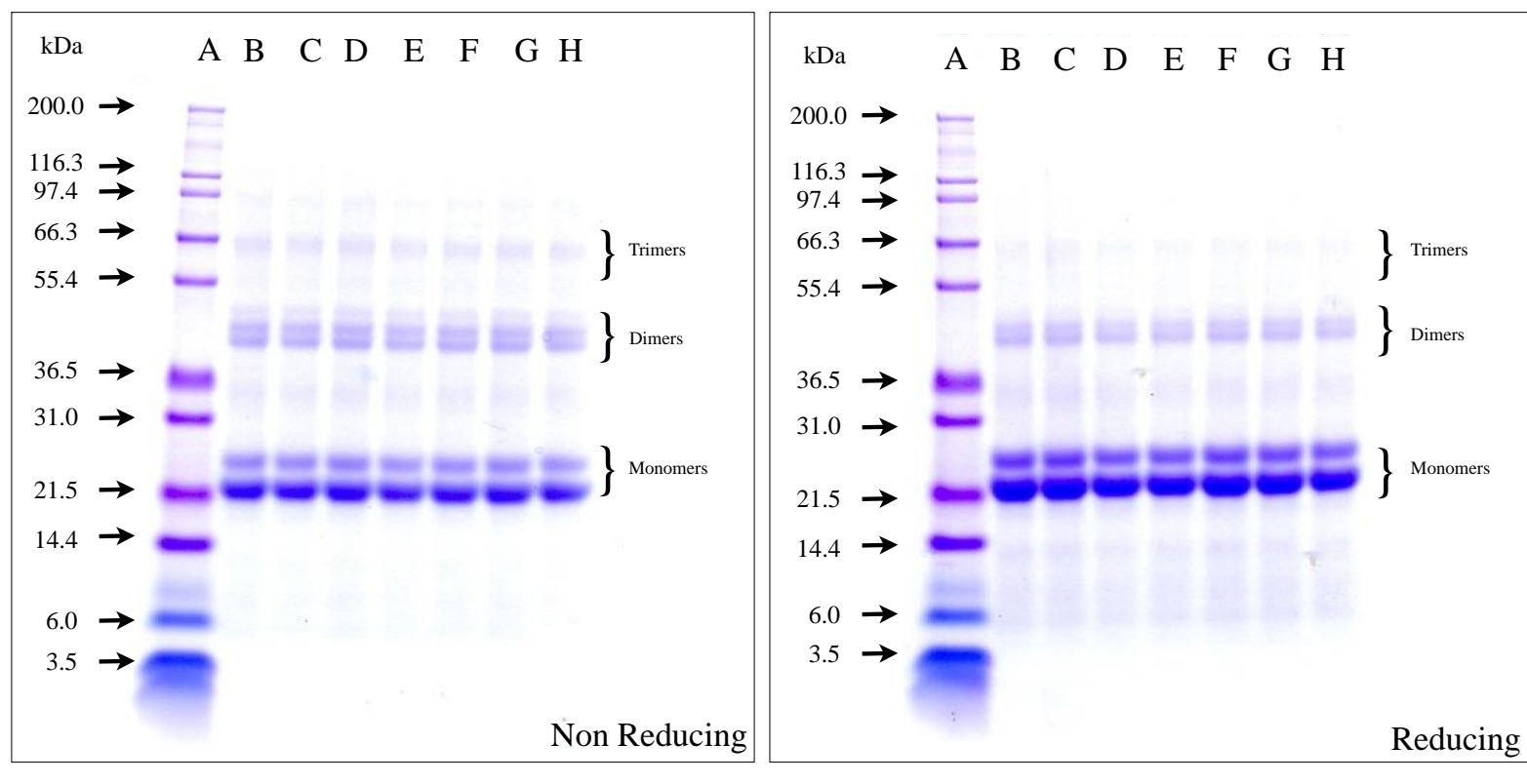

Fig. 2 SDS-PAGE of zein doughs prepared with dilute lactic acid and acetic acid

A, Molecular standards; B, Zein in distilled water; C, Zein in $0.7 \%$ lactic acid; D, Zein in $1.3 \%$ lactic acid; E, Zein in 5.4\% lactic acid; F, Zein in $0.7 \%$ acetic acid; G, Zein in $1.3 \%$ acetic acid; $\mathrm{H}$, Zein in $5.4 \%$ acetic acid. 

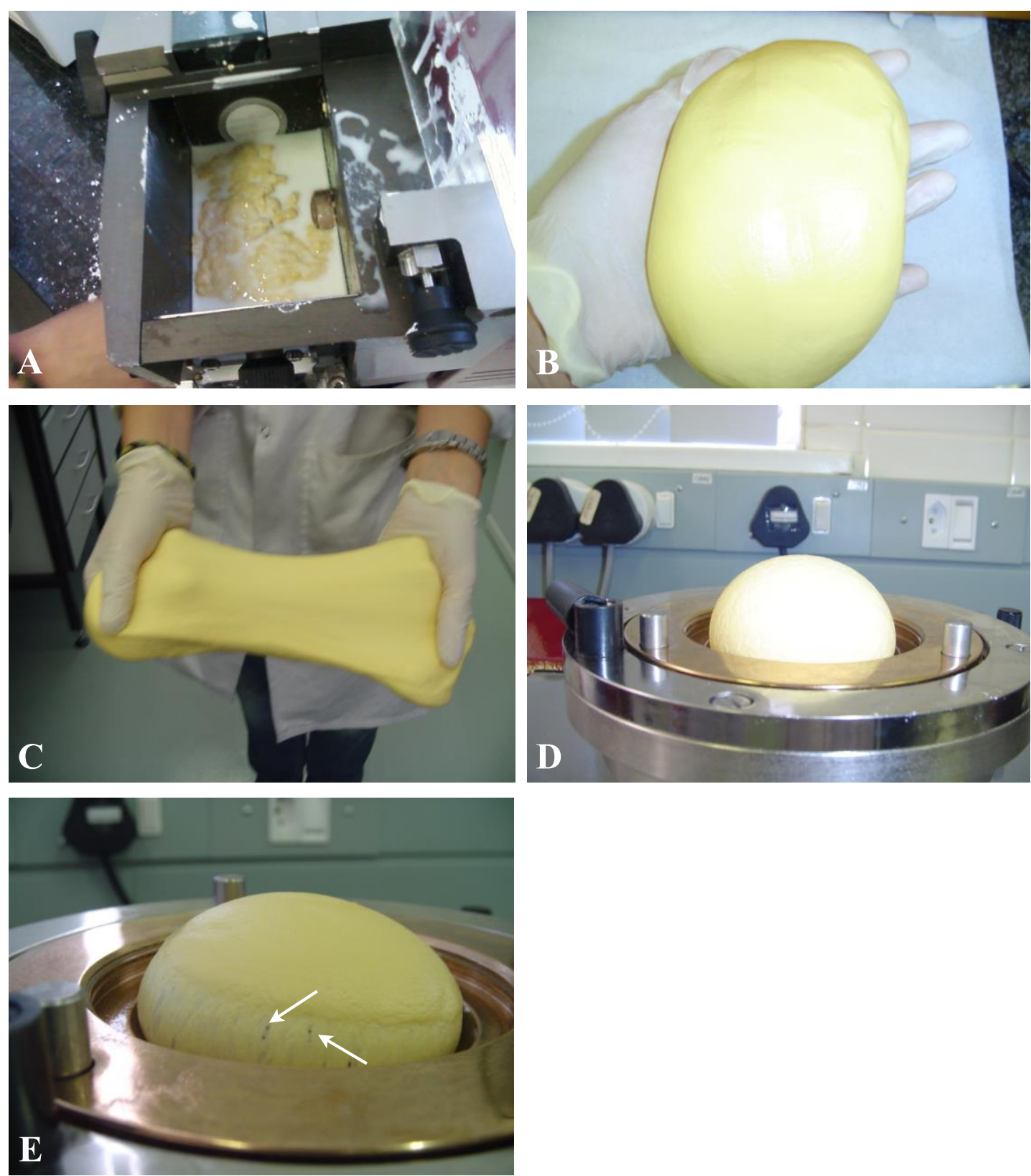

Fig. 3 Zein-maize starch doughs

A, Dough prepared with water after kneading, showing phase separation; B, Dough prepared with $1.3 \%$ lactic acid after kneading; C, Malleability of dough prepared with $1.3 \%$ lactic acid; D: Alveography of dough prepared with $1.3 \%$ lactic acid; E, Loss of uniformity and tearing of Alveograph bubble of dough prepared with 5.4\% lactic acid. 
Table $1 \mathrm{pH}$ and tensile properties of zein doughs prepared with dilute lactic acid and acetic acid ${ }^{1}$

\begin{tabular}{|c|c|c|c|c|c|c|c|c|c|c|}
\hline \multirow[t]{2}{*}{ Treatment } & \multirow{2}{*}{$\begin{array}{c}\text { Acid } \\
\text { concentration } \\
(\% \mathrm{v} / \mathrm{v})\end{array}$} & \multirow[t]{2}{*}{$\begin{array}{c}\text { Dough } \\
\mathrm{pH}\end{array}$} & \multirow{2}{*}{$\begin{array}{l}\text { Peak } \\
\text { Force } \\
(\mathrm{N}) \\
\end{array}$} & \multirow{2}{*}{$\begin{array}{c}\text { Extension } \\
\text { (mm) }\end{array}$} & \multirow{2}{*}{$\begin{array}{l}\text { Peak } \\
\text { stress } \\
(\mathrm{kPa})\end{array}$} & \multicolumn{2}{|c|}{$\begin{array}{c}\text { Strain at } \\
\text { maximum hook } \\
\text { displacement } \\
(150 \mathrm{~mm})\end{array}$} & \multirow{2}{*}{$\begin{array}{l}\text { Extensional } \\
\text { Viscosity } \\
\left(\eta_{\mathrm{E}}, \mathrm{kPa} . \mathrm{s}\right)\end{array}$} & \multirow{2}{*}{$\begin{array}{l}\text { Young's } \\
\text { Modulus } \\
(E, \mathrm{kPa})\end{array}$} & \multirow[t]{2}{*}{$\begin{array}{c}\text { Area } \\
\text { under } \\
\text { stress- } \\
\text { strain } \\
\text { curve } \\
\text { (N.mm) }\end{array}$} \\
\hline & & & & & & $(\%)$ & $\left(\varepsilon_{\mathrm{H}}\right)^{2}$ & & & \\
\hline $\begin{array}{c}\text { Distilled } \\
\text { water }\end{array}$ & 0 & 3.90 & $\begin{array}{l}{ }^{3} 3.47^{\mathrm{a}} \\
\pm 0.43\end{array}$ & ${ }^{4} 270$ & $\begin{array}{l}122.8^{\mathrm{a}} \\
\pm 10.8\end{array}$ & $\begin{array}{c}1002^{\mathrm{a}} \\
\pm 4\end{array}$ & $\begin{array}{c}2.31^{\mathrm{a}} \\
\pm 0.00\end{array}$ & $\begin{array}{l}5625^{\mathrm{a}} \\
\pm 510\end{array}$ & $\begin{array}{l}29.8^{\mathrm{a}} \\
\pm 0.4\end{array}$ & $\begin{array}{l}612^{\mathrm{a}} \\
\pm 51\end{array}$ \\
\hline \multirow{3}{*}{ Lactic acid } & 0.7 & 3.28 & $\begin{array}{c}3.25^{\mathrm{a}} \\
\pm 0.67\end{array}$ & 270 & $\begin{array}{l}114.9^{\mathrm{a}} \\
\pm 23.5\end{array}$ & $\begin{array}{c}1000^{\mathrm{a}} \\
\pm 6\end{array}$ & $\begin{array}{c}2.30^{\mathrm{a}} \\
\pm 0.01\end{array}$ & $\begin{array}{l}5251^{\mathrm{a}} \\
\pm 756\end{array}$ & $\begin{array}{l}31.1^{\mathrm{a}} \\
\pm 5.4\end{array}$ & $\begin{array}{c}612^{\mathrm{a}} \pm \\
135\end{array}$ \\
\hline & 1.3 & 3.13 & $\begin{array}{c}2.40^{\mathrm{b}} \\
\pm 0.44\end{array}$ & 270 & $\begin{array}{c}84.8^{\mathrm{b}} \\
\pm 15.5\end{array}$ & $\begin{array}{c}1003^{\mathrm{a}} \\
\pm 2\end{array}$ & $\begin{array}{c}2.31^{\mathrm{a}} \pm \\
0.00\end{array}$ & $\begin{array}{l}3888^{\mathrm{b}} \\
\pm 314\end{array}$ & $\begin{array}{l}19.8^{\mathrm{b}} \\
\pm 4.0\end{array}$ & $\begin{array}{l}440^{\mathrm{b}} \\
\pm 69\end{array}$ \\
\hline & 5.4 & 2.47 & $\begin{array}{c}0.52^{\mathrm{c}} \\
\pm 0.10\end{array}$ & 270 & $\begin{array}{l}18.2^{\mathrm{c}} \\
\pm 3.6\end{array}$ & $\begin{array}{c}1002^{\mathrm{a}} \\
\pm 2\end{array}$ & $\begin{array}{c}2.31^{\mathrm{a}} \\
\pm 0.00\end{array}$ & $\begin{array}{c}834^{\mathrm{c}} \\
\pm 165\end{array}$ & $\begin{array}{l}10.3^{c} \\
\pm 7.6\end{array}$ & $\begin{array}{l}118^{\mathrm{c}} \\
\pm 18\end{array}$ \\
\hline \multirow{3}{*}{ Acetic acid } & 0.7 & 3.48 & $\begin{array}{c}3.15^{\mathrm{a}} \\
\pm 0.40\end{array}$ & 270 & $\begin{array}{l}111.6^{\mathrm{a}} \\
\pm 14.2\end{array}$ & $\begin{array}{c}1001^{\mathrm{a}} \\
\pm 4\end{array}$ & $\begin{array}{l}2.30^{\mathrm{a}} \\
\pm 0.00\end{array}$ & $\begin{array}{l}5104^{\mathrm{a}} \\
\pm 645\end{array}$ & $\begin{array}{l}30.7^{\mathrm{a}} \\
\pm 2.6\end{array}$ & $\begin{array}{l}547^{\mathrm{a}} \\
\pm 91\end{array}$ \\
\hline & 1.3 & 3.40 & $\begin{array}{c}2.00^{\mathrm{b}} \\
\pm 0.14\end{array}$ & 270 & $\begin{array}{l}70.9^{\mathrm{b}} \\
\pm 4.9\end{array}$ & $\begin{array}{c}996^{\mathrm{a}} \\
\pm 6\end{array}$ & $\begin{array}{c}2.30^{\mathrm{a}} \pm \\
0.01\end{array}$ & $\begin{array}{l}3227^{\mathrm{b}} \\
\pm 204\end{array}$ & $\begin{array}{c}20.9^{\mathrm{b}} \pm \\
0.9\end{array}$ & $\begin{array}{l}316^{\mathrm{b}} \\
\pm 21\end{array}$ \\
\hline & 5.4 & 3.11 & $\begin{array}{c}0.25^{\mathrm{c}} \\
\pm 0.10 \\
\end{array}$ & 270 & $\begin{array}{r}9.0^{\mathrm{c}} \\
\pm 3.7 \\
\end{array}$ & $\begin{array}{l}984^{\mathrm{b}} \\
\pm 12 \\
\end{array}$ & $\begin{array}{l}2.29^{\mathrm{b}} \\
\pm 0.01 \\
\end{array}$ & $\begin{array}{r}404^{\mathrm{c}} \\
\pm 169 \\
\end{array}$ & $\begin{array}{l}15.8^{\mathrm{c}} \\
\pm 2.5 \\
\end{array}$ & $\begin{array}{r}48^{\mathrm{c}} \\
\pm 83 \\
\end{array}$ \\
\hline
\end{tabular}

${ }^{1}$ Means \pm Standard Deviation of three replicates

${ }^{2}$ Hencky strain/true strain

${ }^{3}$ Values in columns with different superscript letters differ significantly $(\mathrm{p}<0.05)$

${ }^{4}$ Dough did not break before maximum hook displacement $(150 \mathrm{~mm})$ 
Table 2 FTIR of freshly prepared zein doughs at $40^{\circ} \mathrm{C}$ prepared with dilute lactic acid and acetic acid 1

\begin{tabular}{|c|c|c|c|c|c|}
\hline Treatment & $\begin{array}{c}\text { Acid concentration } \\
(\% \mathrm{v} / \mathrm{v})\end{array}$ & $\begin{array}{c}\alpha \text {-helix } \\
\text { Wavenumber }\left(\mathrm{cm}^{-1}\right)\end{array}$ & $\begin{array}{c}\beta \text {-sheet } \\
\text { Wavenumber }\left(\mathrm{cm}^{-1}\right)\end{array}$ & $\alpha: \beta$ ratio & $\begin{array}{c}\text { Relative } \\
\alpha \text {-helical conformation }(\%)\end{array}$ \\
\hline & & \multicolumn{4}{|c|}{ Amide I } \\
\hline Zein powder & Not applicable & ${ }^{2} 1645^{\mathrm{e}} \pm 1$ & $1619^{\mathrm{a}} \pm 1$ & $1.52^{\mathrm{d}} \pm 0.09$ & 60.3 \\
\hline Distilled water & 0 & $1643^{\mathrm{ab}} \pm 1$ & $1626^{b c} \pm 1$ & $1.05^{\mathrm{a}} \pm 0.03$ & 51.2 \\
\hline \multirow{3}{*}{ Lactic acid } & 0.7 & $1643^{\mathrm{a}} \pm 1$ & $1628^{\mathrm{c}} \pm 1$ & $1.08^{\mathrm{ab}} \pm 0.05$ & 51.8 \\
\hline & 1.3 & $1641^{\mathrm{a}} \pm 1$ & $1628^{c} \pm 1$ & $1.08^{a b} \pm 0.04$ & 51.8 \\
\hline & 5.4 & $1644^{\text {cde }} \pm 1$ & $1624^{b} \pm 1$ & $1.25^{\mathrm{c}} \pm 0.03$ & 55.6 \\
\hline \multirow{3}{*}{ Acetic acid } & 0.7 & $1644^{a b c} \pm 0$ & $1626^{b c} \pm 1$ & $1.10^{\mathrm{ab}} \pm 0.04$ & 52.3 \\
\hline & 1.3 & $1644^{\mathrm{bcd}} \pm 1$ & $1628^{c} \pm 1$ & $1.13^{b} \pm 0.03$ & 53.1 \\
\hline & 5.4 & $1645^{\mathrm{de}} \pm 0$ & $1626^{b c} \pm 1$ & $1.22^{\mathrm{c}} \pm 0.03$ & 55.0 \\
\hline
\end{tabular}

${ }^{1}$ Mean \pm Standard Deviation of three replicates, ${ }^{2}$ Values within a column block with different superscript letters differ significantly $(\mathrm{p}<0.05)$ 
Table 3 Alveograph behaviour of zein-maize starch and zein-rice flour dough prepared with dilute lactic acid and acetic acid ${ }^{1}$

\begin{tabular}{|c|c|c|c|c|c|}
\hline Treatment & $\begin{array}{l}\text { Acid concentration } \\
\qquad(\% \mathrm{v} / \mathrm{v})\end{array}$ & $\begin{array}{l}\text { Stability } \\
\text { (P) }\end{array}$ & $\begin{array}{c}\text { Distensibility } \\
\text { (L) }\end{array}$ & $\begin{array}{c}\text { Curve configuration } \\
\text { Ratio } \\
(\mathrm{P} / \mathrm{L})\end{array}$ & $\begin{array}{c}\text { Deformation Energy } \\
\left(\mathrm{W}, \mathrm{J} \times 10^{-4}\right)\end{array}$ \\
\hline Bread wheat flour & 0 & ${ }^{2} 103.2^{\mathrm{de}} \pm 10.3$ & $79.6^{\mathrm{a}} \pm 16.9$ & $1.36^{\mathrm{d}} \pm 0.40$ & $301.2^{\mathrm{c}} \pm 28.9$ \\
\hline \multicolumn{6}{|c|}{ Zein-maize starch doughs } \\
\hline Distilled water & 0 & Dough was not forn & & & \\
\hline Lactic acid & $\begin{array}{l}0.7 \\
1.3 \\
5.4\end{array}$ & $\begin{array}{l}75.4^{\mathrm{bc}} \pm 9.2 \\
92.2^{\mathrm{cde}} \pm 8.5 \\
41.4^{\mathrm{a}} \pm 10.8\end{array}$ & $\begin{array}{c}81.6^{\mathrm{a}} \pm 30.4 \\
176.5^{\mathrm{c}} \pm 45.9 \\
83.0^{\mathrm{a}} \pm 25.2\end{array}$ & $\begin{array}{c}0.84^{\mathrm{bc}} \pm 0.18 \\
0.44^{\mathrm{a}} \pm 0.23 \\
0.51^{\mathrm{ab}} \pm 0.12\end{array}$ & $\begin{array}{c}166.0^{\mathrm{b}} \pm 35.6 \\
302.6^{\mathrm{c}} \pm 47.9 \\
44.0^{\mathrm{a}} \pm 0.2\end{array}$ \\
\hline Acetic acid & $\begin{array}{l}0.7 \\
1.3 \\
5.4\end{array}$ & $\begin{array}{c}90.0^{\mathrm{cd}} \pm 8.3 \\
106.0^{\mathrm{def}} \pm 10.7 \\
52.2^{\mathrm{a}} \pm 7.5\end{array}$ & $\begin{array}{c}140.2^{\mathrm{bc}} \pm 38.2 \\
179.8^{\mathrm{c}} \pm 27.6 \\
67.3^{\mathrm{a}} \pm 20.9\end{array}$ & $\begin{array}{l}0.82^{\mathrm{abc}} \pm 0.39 \\
0.65^{\mathrm{abc}} \pm 0.20 \\
0.84^{\mathrm{abc}} \pm 0.30 \\
\end{array}$ & $\begin{array}{c}328.0^{\mathrm{cd}} \pm 79.3 \\
310.4^{\mathrm{c}} \pm 46.2 \\
49.0^{\mathrm{a}} \pm 7.1\end{array}$ \\
\hline \multicolumn{6}{|c|}{ Zein-rice flour doughs } \\
\hline Distilled Water & 0 & \multicolumn{3}{|c|}{ Dough too soft and not cohesive enough to measure } & \\
\hline Lactic acid & $\begin{array}{l}0.7 \\
1.3 \\
5.4\end{array}$ & $\begin{array}{c}123.8^{\mathrm{f}} \pm 5.6 \\
106.0^{\mathrm{def}} \pm 17.5 \\
86.8^{\mathrm{cd}} \pm 8.3\end{array}$ & $\begin{array}{l}164.0^{\mathrm{c}} \pm 39.4 \\
185.5^{\mathrm{c}} \pm 26.8 \\
91.2^{\mathrm{ab}} \pm 27.0\end{array}$ & $\begin{array}{c}0.84^{\mathrm{bc}} \pm 0.22 \\
0.66^{\mathrm{abc}} \pm 0.22 \\
1.00^{\mathrm{cd}} \pm 0.23\end{array}$ & $\begin{array}{c}420.4^{\mathrm{e}} \pm 87.2 \\
335.3^{\mathrm{cde}} \pm 77.8 \\
158.8^{\mathrm{b}} \pm 31.7\end{array}$ \\
\hline Acetic acid & $\begin{array}{l}0.7 \\
1.3 \\
5.4\end{array}$ & $\begin{array}{l}113.0^{\text {ef }} \pm 18.1 \\
97.7^{\mathrm{de}} \pm 16.6 \\
59.6^{\mathrm{ab}} \pm 16.4\end{array}$ & $\begin{array}{c}153.4^{\mathrm{c}} \pm 38.3 \\
141.7^{\mathrm{bc}} \pm 44.5 \\
90.6^{\mathrm{ab}} \pm 30.3\end{array}$ & $\begin{array}{c}0.85^{\mathrm{bc}} \pm 0.38 \\
0.87^{\mathrm{abc}} \pm 0.48 \\
0.85^{\mathrm{bc}} \pm 0.45\end{array}$ & $\begin{array}{c}412.0^{\mathrm{de}} \pm 65.0 \\
369.0^{\mathrm{cde}} \pm 28.2 \\
117.0^{\mathrm{ab}} \pm 59.1\end{array}$ \\
\hline
\end{tabular}

${ }^{1}$ Mean \pm Standard Deviation of three replicate assay

${ }^{2}$ Values in columns with different superscript letters differ significantly $(\mathrm{p}<0.05)$ 